Patricia Rodrigues Lourenço Gomes ${ }^{1}$

ISMAEL Forte Frettas JUNIOR ${ }^{2}$ Camila Buonani da Silva ${ }^{3}$ IgOR CONTERATO GOMES ${ }^{4}$ Ana Paula Rodrigues Rocha ${ }^{5}$ Afonso Shiguemi InOue Salgado ${ }^{6}$ EDNA MARIA DO CARMO ${ }^{7}$

Original Article

Keywords

Hand strength

Body composition Lymphedema Breast cancer

Palavras-chave

Força da mão Composição corporal

Linfedema

Câncer de mama

Correspondence

Patricia Rodrigues Lourenço Gomes Department of Physiology and Biophysics, ICBI, Universidade de São Paulo Avenida Professor Lineu Prestes, 1.524 (EP: 05508-000

São Paulo (SP), Brazil

Received

04/17/2014

Accepted with modifications

05/19/2014

\section{Short-term changes in handgrip strength, body composition, and lymphedema induced by breast cancer surgery}

\author{
Alterações a curto prazo na força de preensão palmar, composição \\ corporal e linfedema induzido pela cirurgia do câncer de mama
}

Abstract

PURPOSE: This study investigated short-term changes in body composition, handgrip strength, and presence of lymphedema in women who underwent breast cancer surgery. METHODS: Ninety-five women participated in a cross-sectional study, divided into two groups: Control $(n=46)$, with healthy women, and Experimental $(n=49)$, with women six months after breast cancer surgery. The Experimental Group was subdivided into right total mastectomy (RTM, $n=15$ ), left total mastectomy (LTM, $n=11)$, right quadrant $(R Q, n=13)$, and left quadrant $(L Q, n=10)$. It was also redistributed among women with presence $(n=10)$ or absence $(n=39)$ of lymphedema. Presence of lymphedema, handgrip strength, and body composition were assessed. RESULTS: Trunk lean mass and handgrip strength were decreased in the Experimental Group. Total lean mass was increased in the LTM compared to RTM or LQ. Left handgrip strength in LTM was decreased compared to RTM and RQ and in $L Q$ compared to RTM and RQ. Finally, total lean mass, trunk fat mass, trunk lean mass, right and left arm lean mass were increased in women with lymphedema. CONCLUSIONS: Breast cancer survivors have changes in their body composition and in handgrip strength six months after surgery; however, the interaction between the type of surgery and its impact is unclear. Furthermore, women who developed lymphedema in this period showed more significant changes in the body composition, but they were not enough to cause impairment in handgrip strength.

\section{Resumo}

OBJETIVO: Este estudo investigou alterações de curto prazo na composição corporal, na força de preensão palmar e na presença de linfedema em mulheres submetidas à cirurgia do câncer de mama. MÉTODOS: Noventa e cinco mulheres participaram de um estudo transversal, sendo divididas em dois grupos: Controle $(n=46)$, mulheres saudáveis, e Experimental ( $n=49$ ), mulheres seis meses após cirurgia do câncer de mama. $\bigcirc$ Grupo Experimental foi subdividido em mastectomia total direita (RTM, $n=15)$, mastectomia total esquerda (LTM, $n=11)$, quadrantectomia direita (RQ, $n=13)$ e quadrantectomia esquerda $(L Q, n=10)$. Também foi redistribuído entre mulheres com presença $(n=10)$ ou ausência (n=39) de linfedema. Foram avaliadas a presença de linfedema, a força de preensão palmar e a composição corporal. RESULTADOS: A massa magra de tronco e a força de preensão palmar estavam diminuídas no Grupo Experimental. Massa magra total estava aumentada na LTM comparada à RTM ou $L Q$. Força de preensão palmar esquerda na LTM estava diminuída comparada à $R T M$ e $R Q$ e em $L Q$ comparada à $R T M$ e $R Q$. Finalmente, massa magra total, magra e gorda de tronco e massa magra de braço esquerdo e direito estavam aumentadas em mulheres com linfedema. CONCLUSÕES: Sobreviventes do câncer de mama possuem alterações na composição corporal e na força de preensão palmar seis meses após a cirurgia, porém a interação entre o tipo de cirurgia e seu impacto não está clara. Além disso, mulheres que desenvolveram linfedema neste período mostraram alterações mais significantes na composição corporal, mas que não foram suficientes para causar prejuízo na força de preensão palmar.
Study Center and Care in Physiotherapy and Rehabilitation - CEAFIR - Universidade de São Paulo - USP - Presidente Prudente (SP), Brazil. IInstitute of Biomedical Sciences, Universidade de São Paulo - USP - São Paulo (SP), Brazil.

2Department of Physical Education, Universidade Estadual Paulista "Júlio de Mesquita Filho" - Unesp - Presidente Prudente (SP), Brazil. "Department of Physical Education, Universidade Estadual Paulista "Júlio de Mesquita Filho" - Unesp - Rio Claro (SP), Brazil. ${ }^{4}$ Department of Epidemiology, Universidade de São Paulo - USP - São Paulo (SP), Brazil.

${ }^{5}$ Department of Physioterapy, Universidade Estadual Paulista "Júlio de Mesquita Filho" - UNESP - Presidente Prudente (SP), Brazil ¿Department of Physiotherapy, CESUMAR - Maringá (PR), Brazil.

'Department of Physioterapy, Universidade Estadual Paulista "Júlio de Mesquita Filho" - Unesp - Presidente Prudente (SP), Brazil. Conflict of interests: none. 


\section{Introduction}

Despite advances in the surgical methods used for breast cancer treatment, the postsurgery period is crucial due to the possibility of developing complications, such as lymphedema, reduction in muscle function, decrease in upper limb muscle, and handgrip strength ${ }^{1,2}$.

With improved outcomes and more women surviving breast cancer, long-term morbidities of treatment, including lymphedema, gain importance. The most evident clinical manifestation is a significant increase in the volume of the injured limb, which is the result of an impairment in the ability of the lymphatic system to drain proteins and macromolecules of the interstitium. Lymphedema-associated signs and symptoms are increased limb diameter, stiffness, and decreased range of movement of affected limb joints, sensory disorders in the hand, and decrease in the limb use for functional tasks ${ }^{3}$.

In addition to the existence of lymphedema, symptoms such as reduced shoulder-neck mobility $^{4}$, shoulder-neck pain ${ }^{5}$, fatigue ${ }^{6}$, decrease upper limb strength ${ }^{7}$ have been demonstrated in survivors. These symptoms promote functional limitations like decreased levels of physical activity and weight gain ${ }^{8}$. Loss of lean mass and simultaneous gains in fat mass are amongst the most common side effects following treatment for breast cancer ${ }^{9}$, and it is becoming an important marker for women who have been diagnosed ${ }^{10}$, 50 to $96 \%$ of those submitted to a mastectomy show an increase in fat mass after surgery ${ }^{11}$.

The assessment of muscle strength by the handgrip strength test has been widely utilized in different conditions, for example, in breast cancer survivors. It is the most frequently used indicator of the muscle function and functional capacity for clinical purposes ${ }^{12}$ and it is an important correlate of health. Handgrip strength test can be recommended as an adjuvant method of assessment, which can help with efficiency of clinical practice ${ }^{2}$.

Body composition, lymphedema, and handgrip strength are intrinsically associated with breast cancer. Analyzing the impact of these postsurgical symptoms can optimize the treatment program and prognosis. Therefore, the aim of this study was to investigate short-term changes in body composition, handgrip strength, and presence of lymphedema in women who underwent breast cancer surgery.

\section{Methods}

\section{Patient selection}

A total of 95 women participated in a cross-sectional study, which was carried out from May to December 2013. The volunteers were divided into two groups:
Control (CG), that consisted of 46 women aged 51 to 54 years, without active disease or osteoarticular limitations; and the Experimental Group (EG), including 49 women who underwent total mastectomy and concomitant sentinel lymph node biopsy or quadrantectomy from November 2012 to June 2013, as well as adjuvant treatment. These volunteers were referred to the Study Center and Care in Physiotherapy and Rehabilitation (CEAFIR) six months after surgery, and all assessments were conducted at such period of time.

The EG was subdivided according to the type of surgery, as follows: right total mastectomy (RTM, $\mathrm{n}=15$ ); left total mastectomy (LTM, $\mathrm{n}=11$ ); right quadrantectomy (RQ, $\mathrm{n}=13)$; and left quadrantectomy (LQ, $\mathrm{n}=10$ ). It was also redistributed among women with presence $(n=10)$ or absence $(n=39)$ of lymphedema. Women presenting bilateral breast cancer surgery or bilateral lymphedema, being ambidextrous, performing radiotherapy or chemotherapy at the time of the study and having orthopedic diseases were excluded from the investigation.

The Ethics Committee of Faculdade de Ciências e Tecnologia of Universidade Estadual Paulista "Júlio de Mesquita Filho" - FCT/Unesp (protocol number 27/2010) approved the study according to the National Committee for Ethics in Research (CONEP). All women provided the informed written consent, which included consent for participation in the study and to publish the findings.

\section{Design}

The volunteers (CG and EG) underwent a medical history and a physical assessment at the CEAFIR from FCT/Unesp. Both medical history and physical assessment were conducted by two physiotherapists who remained together in all assessments until the end of the study. Presence of lymphedema, handgrip strength, and body composition were measured six months after breast cancer surgery (from May to December 2013).

\section{Lymphedema}

Lymphedema was evidenced by segmental arm circumference. Measurements were obtained 5, 10, 15, and $20 \mathrm{~cm}$ above and below the bilateral antecubital fossa on the ipsilateral and contralateral limbs. Presence of lymphedema was considered when there was a difference exceeding $1 \mathrm{~cm}$ compared to the contralateral limb and to the CG, therefore, from the mild degree ${ }^{13}$.

Each point $(5,10,15$, and $20 \mathrm{~cm})$ was measured three times and the final result was determined by the mean values. To perform the segmental arm circumference, it was used an inextensible metallic tape of the Sanny ${ }^{\circledR}$ brand (American Medical of Brasil Ltda., Sao Paulo, Brazil), with $0.1 \mathrm{~cm}$ precision and $2 \mathrm{~m}$ maximum extension. 


\section{Handgrip strength}

A calibrated dynamometer was used to assess handgrip strength (Hydraulic Hand Dynamometer SH5001, SAEHAN Corporation) with response values in kilogram-force (kgf). Women were comfortably seated on a chair without armrests. The shoulder was adductive and neutrally rotated, with the elbow at a $90^{\circ}$ flexion, and the forearm and wrist in a neutral position.

Women were instructed to grip the dynamometer with maximum strength in response to a voice command and after returning to neutral condition. Three trials were performed on each side, alternately, with a rest period of at least one minute between trials of the same hand. The highest value of each side was used to represent the handgrip strength. Contralateral limb and CG were used as standard. The CG values were standardized according to a cross-sectional study conducted in 3,050 healthy adults ${ }^{14}$.

\section{Body composition}

Body composition was measured through the Dual Energy X-ray Absorptiometry (DEX), Lunar DPX-NT model (Lunar/GE Corp, Madison, Wisconsin), software 4.7 , which uses the model of three compartments (lean body mass, fat mass, and body mineral). This technique allows measuring total body composition and segment. The procedure lasted approximately 15 minutes and did not require aid of volunteers, however, participants should remain in a supine position with their feet in a neutral position and hands flat by their sides.

During the assessment, the following data were analyzed: percentage of total fat (\%), fat mass $(\mathrm{kg})$, and lean mass $(\mathrm{kg})$ in trunk and upper limbs. The cut points between arms and trunk were determined by using software calculations. For technical error calculation of the DEX, 12 women who did not participate in the study were assessed for two consecutive days, by at least an evaluator. Based on the results obtained, the estimated error was: $1.48 \%$ in total body fat, $1.38 \%$ in trunk fat mass, $2.06 \%$ in total lean mass, and $2.79 \%$ in bone mineral density. The CG was used as standard. The CG values were standardized according to a cross-sectional study conducted in 5,635 healthy adults ${ }^{15}$.

\section{Statistical analysis}

The Kolmogorov-Smirnov (KS) normality test was applied to determine the composition of all data analyzed in the Gaussian distribution model, and the parametric analysis was based on the parameters derived from the KS.

The sample characterization was presented by descriptive analysis for age, weight and height.
The mean and standard error were analyzed. For such variables, the Student's $t$-test (independent samples) was used with means of comparison between the groups. For the EG, the frequency was calculated according to the type of surgery and presence or absence of lymphedema.

The Student's $t$-test (independent samples) was used to compare the two groups that presented presence or absence of lymphedema. After division of the EG, the normality of data was tested with the KS test. Nonparametric methods were applied, and the comparison was performed using Kruskal-Wallis test. All analyses were conducted using the program SPSS, version 17.0 (SPSS Inc, Chicago, IL) and a $5 \%$ statistical significance.

\section{Results}

Table 1 presents the general characteristics of the CG and EG. Age, weight, and height were homogeneous between groups, and $95 \%$ of women were right-handed. All women in the EG underwent simultaneous adjuvant therapy (chemotherapy, radiotherapy or hormone therapy), $20 \%$ had lymphedema six months after surgery and quadrantectomy, and mastectomy - right or left - showed a similar distribution in the EG.

Table 1. General characteristics

\begin{tabular}{|c|c|c|c|}
\hline Characteristics & CG & EG & p-value \\
\hline Age (years) & $52.7(0.8)$ & $54.2(1.1)$ & 0.3 \\
\hline Weight (kg) & $67.7(2.3)$ & $68.2(1.9)$ & 0.8 \\
\hline Height (cm) & $1.57(0.8)$ & $1.57(0.9)$ & 1.0 \\
\hline \multicolumn{4}{|l|}{ Upper limb dominance } \\
\hline Right-handed & $44(95.6 \%)$ & $47(95.9 \%)$ & - \\
\hline Left-handed & $2(4.3 \%)$ & $2(4.0 \%)$ & - \\
\hline \multicolumn{4}{|l|}{ Adjuvant treatment } \\
\hline Chemotherapy & - & $34(69.3 \%)$ & - \\
\hline Radiotherapy & - & $31(63.2 \%)$ & - \\
\hline Hormone therapy & - & $18(36.7 \%)$ & - \\
\hline \multicolumn{4}{|l|}{ Lymphedema } \\
\hline Present & - & $10(20.4 \%)$ & - \\
\hline Absent & - & $39(79.5 \%)$ & - \\
\hline \multicolumn{4}{|l|}{ Surgery } \\
\hline Left quadrantectomy & - & $10(20.4 \%)$ & - \\
\hline Right quadrantectomy & - & $13(25.5 \%)$ & - \\
\hline Left total mastectomy & - & $11(22.4 \%)$ & - \\
\hline Right total mastectomy & - & $15(30.6 \%)$ & - \\
\hline
\end{tabular}

Data presented as mean \pm standard error or number and percentage. ${ }^{*} \mathrm{p}$-value $\leq 0.05$

Student's ftest (independent samples); CG: Control Group ( $n=46$ ); EG: Experimental Group $(n=49)$. 
The results of body composition and handgrip strength between CG and EG are given in Table 2. Trunk lean mass was decreased in the EG compared to the CG ( $\mathrm{p}=0.04)$. Right and left handgrip strengths were lower in the EG compared to CG ( $\mathrm{p}=0.0001)$; however, right and left handgrip strengths between the sides are similar in the EG.

Table 3 presents the body composition and handgrip strength according to the type of surgery - LTM, RTM, $\mathrm{RQ}$, and LQ. Total lean mass was higher in women who underwent LTM compared to RTM or LQ $(p=0.04)$.

Left handgrip strength in LTM was decreased compared to RTM and RQ ( $=0.001)$ and in LQ compared to RTM and RQ ( $\mathrm{p}=0.001)$.

Table 2. Body composition and handgrip strength

\begin{tabular}{llll}
\hline Characteristics & \multicolumn{1}{c}{ CG } & EG & $\dagger$ (p-value) \\
\hline Total fat mass (kg) & $29.5(10.4)$ & $29.3(9.3)$ & $0.1(0.9)$ \\
\hline Total fat (\%) & $43.6(7.7)$ & $44.4(6.4)$ & $0.5(0.5)$ \\
\hline Total lean mass (kg) & $36.6(5.8)$ & $35.6(4.7)$ & $0.8(0.9)$ \\
\hline Trunk lean mass (kg) & $17.3(4.3)$ & $15.9(2.5)$ & $2.0(0.04)^{\star}$ \\
\hline Right arm fat mass (kg) & $12.9(8.4)$ & $14.3(9.3)$ & $1.0(0.2)$ \\
\hline Left arm fat mass (kg) & $12.5(8.3)$ & $13.5(8.9)$ & $0.8(0.4)$ \\
\hline Right arm lean mass (kg) & $20.1(4.8)$ & $19.7(4.8)$ & $0.6(0.5)$ \\
\hline Left arm lean mass (kg) & $20.0(5.2)$ & $19.9(6.2)$ & $0.1(0.9)$ \\
\hline Right handgrip strength (kgf) & $26.3(7.8)$ & $18.3(8.9)$ & $4.6(0.0001)^{\star}$ \\
\hline Left handgrip strength (kgf) & $26.0(8.2)$ & $18.8(9.4)$ & $3.9(0.0001)^{\star}$ \\
\hline
\end{tabular}

Data presented as mean \pm standard error. ${ }^{*}$-value $\leq 0.05$. Student's ktest lindependent samples). CG: Control Group ( $n=46)$; EG: Experimental Group ( $n=49)$.
Body composition and handgrip strength according to the presence or absence of lymphedema are given in Table 4. Total lean mass $(\mathrm{p}=0.004)$, trunk fat mass $(\mathrm{p}=0.05)$, trunk lean mass $(\mathrm{p}=0.005)$, right arm lean mass $(\mathrm{p}=0.03)$, and left arm lean mass $(\mathrm{p}=0.01)$ were increased in women with lymphedema six months after breast cancer surgery. However, handgrip strength was unchanged, regardless of the presence or absence of lymphedema.

Table 4. Comparison of body composition and handgrip strength according to the presence of lymphedema

\begin{tabular}{|c|c|c|c|}
\hline \multirow{2}{*}{ Characteristics } & \multicolumn{2}{|c|}{ Lymphedema } & \multirow{2}{*}{$t$ (p-value) } \\
\hline & Absence & Presence & \\
\hline Total fat mass (kg) & $28.2(8.4)$ & $33.5(11.9)$ & $-1.6(0.1)$ \\
\hline Total body fat (\%) & $44.3(6.8)$ & $45.1(5.2)$ & $-0.3(0.7)$ \\
\hline Total lean mass (kg) & $34.7(3.7)$ & $39.3(6.2)$ & $-3.0(0.004)^{\star}$ \\
\hline Trunk fat mass (kg) & $13.6(4.8)$ & $17.3(6.1)$ & $-2.0(0.05)$ * \\
\hline Trunk lean mass (kg) & $15.4(1.8)$ & $17.8(3.7)$ & $-2.9(0.005)^{\star}$ \\
\hline Right arm lean mass (kg) & $1.9(0.4)$ & $2.2(0.3)$ & $-2.1(0.03)^{\star}$ \\
\hline Left arm lean mass $(\mathrm{kg})$ & $1.9(0.4)$ & $2.3(0.5)$ & $-2.4(0.01)^{*}$ \\
\hline Right arm fat mass (kg) & $1.4(0.6)$ & $1.5(0.8)$ & $-0.4(0.6)$ \\
\hline Right arm fat (\%) & $38.2(7.6)$ & $38.6(9.5)$ & $-0.1(0.8)$ \\
\hline Left arm fat mass (kg) & $1.3(0.6)$ & $1.6(0.8)$ & $-1.2(0.2)$ \\
\hline Left arm fat (\%) & $38.1(7.3)$ & $38.2(8.6)$ & $-0.06(0.9)$ \\
\hline Right handgrip strength (kgf) & $18.6(9.5)$ & $17.4(6.7)$ & $0.3(0.7)$ \\
\hline Left handgrip strength (kgf) & $18.9(10.0)$ & $18.3(7.0)$ & $0.1(0.8)$ \\
\hline
\end{tabular}

Data presented as mean \pm standard error. ${ }^{*} p$-value $\leq 0.05$. Student's ttest lindependent samples); absence $(n=39)$; presence $(n=10)$.

Table 3. Body composition and handgrip strength according to the type of surgery

\begin{tabular}{|c|c|c|c|c|c|}
\hline \multirow{3}{*}{ Characteristics } & \multicolumn{4}{|c|}{ Type of surgery } & \multirow{3}{*}{ p-value } \\
\hline & RTM & LTM & $R Q$ & LQ & \\
\hline & Interquartile (25-75) & Interquartile (25-75) & Interquartile (25-75) & Interquartile (25-75) & \\
\hline Total fat mass (kg) & $25.9(23.6-28.2)$ & $35.2(20.3-41.5)$ & $30.0(24.8-36.5)$ & $26.8(19.6-28.3)$ & 0.2 \\
\hline$\%$ total fat & $42.4(39.1-47.3)$ & $47.6(36.7-52.2)$ & $44.6(42.2-49.6)$ & $43.8(41.0-47.0)$ & 0.6 \\
\hline Total lean mass $(\mathrm{kg})$ & $34.4(33.1-36.8)$ & $36.8(35.0-41.7)^{0}$ & $33.8(32.0-41.2)$ & $32.4(29.9-37.0)^{\mathrm{b}}$ & $0.04^{\star}$ \\
\hline Trunk fat mass (kg) & $12.1(11.2-15.3)$ & $15.3(9.6-20.3)$ & $13.9(12.1-18.4)$ & $13.6(11.0-15.6)$ & 0.4 \\
\hline Trunk lean mass (kg) & $15.7(14.7-16.0)$ & $17.0(15.7-19.3)$ & $14.9(14.5-18.0)$ & $14.7(13.3-16.4)$ & 0.07 \\
\hline Right arm fat mass (kg) & $1.2(0.9-1.6)$ & $1.6(1.2-2.6)$ & $1.3(0.9-2.0)$ & $1.1(0.8-1.3)$ & 0.08 \\
\hline Left arm fat mass (kg) & $1.2(0.9-1.6)$ & $1.5(0.9-1.8)$ & $1.2(1.0-2.1)$ & $1.2(0.8-1.4)$ & 0.4 \\
\hline Right arm lean mass (kg) & $1.9(1.6-2.0)$ & $2.0(1.9-2.4)$ & $2.1(1.7-2.5)$ & $1.8(1.6-2.3)$ & 0.2 \\
\hline Left arm lean mass (kg) & $2.0(1.8-2.3)$ & $2.0(1.6-2.4)$ & $2.0(1.7-2.5)$ & $1.9(1.5-2.3)$ & 0.6 \\
\hline
\end{tabular}

Data presented as median and interquartile $25^{\text {th }}$ to $75^{\text {th }}$. Kruskal-Wallis. * $p$-value $\leq 0.05$. apost hoc test with $p<0.05$ compared to RTM; bpost hoc test with $p<0.05$ compared to LTM; cpost hoc test with $p<0.05$ compared to $R Q$; RTM: right total mastectomy ( $n=15)$; LTM: left total mastectomy ( $n=1$ 1); $R Q$ : right quadrantectomy (n=13); $L Q$ : left quadrantectomy $(n=10)$. 


\section{Discussion}

Approximately 230,000 women were diagnosed with invasive breast cancer in $2011^{16}$. Death rates have decreased significantly over the past two decades, with five-year survival rates of approximately $90 \%{ }^{17}$. Although adjuvant therapy combinations have improved survival, there are reports of weight gain and unfavorable changes in body composition $^{11,18}$. Furthermore, several authors postulated that breast cancer survivors exhibit reduction in muscle strength associated with cancer-related symptoms ${ }^{7,19,20}$.

Based on the results, it was observed that women who underwent surgical treatment for breast cancer showed decrease in trunk lean mass and in the right and left handgrip strengths compared to the CG. However, handgrip strength between the sides was similar in EG therefore, in this case, the dominance among upper limbs was not decisive. The surgical procedure promoted impairment in handgrip strength between the groups.

Prospective studies have shown that muscular strength, as measured by the handgrip strength test, is inversely associated with all-cause mortality ${ }^{21-24}$. A cross-sectional study including 95 breast cancer survivors in the initial stage therapy (6 mos maximum) indicated several factors that are negatively associated with handgrip strength such as mood, fatigue, pain, hypersensitivity, neck-shoulder mobility, fitness level, and physiologic parameters ${ }^{2}$.

For breast cancer survivors, simultaneous lean mass loss with fat tissue accumulation, known as sarcopenic obesity, is common ${ }^{25,26}$. The complete etiology of lean mass loss in this population is unclear, however it seems to be associated with poorer metabolic outcomes, such as earlier onset of cardiovascular disease and metabolic syndrome related diseases ${ }^{27-29}$. Inflammatory mediators present as a result of the disease state and treatment ${ }^{30,31}$.

Such findings could also happen due to breast cancer surgery, which affects the musculoskeletal components and prolong the immobilization of the limb leading to a decreased range of motion, retention of metabolites and swelling, and even fibrous tissue ${ }^{32}$. In addition, cancer treatment, specially chemotherapy, promotes disruption in muscle metabolism (adenosine triphosphate dysregulation, cytokine dysregulation, deprivation of satellite cells) and leads to wasting, which may impair muscle strength ${ }^{33}$ and reduce fitness level.

Several studies reported body composition changes in women after breast cancer, but the relationship between body composition and type of breast cancer surgery is not documented $^{1,9,11,18}$. In this study, women who underwent LTM showed increased total lean mass compared to RTM and LQ. Upper limb lean mass and fat mass did not differ among types of surgery or between sides. The mechanism by which this occurs is unclear. The increase in trunk lean mass could be related to causes regardless of the type of surgery. Another hypothesis for this finding is that the assessment period is the threshold to begin remodeling body composition.

In contrast, the left handgrip strength in women who underwent LTM and LQ was decreased compared to RTM and RQ. These data showed the relationship between the operated limb and dominance. Besides high percentage of right-handed women in the study, it is likely that women who underwent LTM and LQ already presented lower left handgrip strength that could have been evidenced after surgery, since that ipsilateral limb is most commonly affected ${ }^{34}$.

Finally, $20.4 \%$ of women had lymphedema six months after surgery, and body composition changes were more evident compared to women who did not develop lymphedema. Studies suggest that from 6 to $40 \%$ of breast cancer survivors will develop lymphedema at some point during their lifetime $e^{35-37}$. Dylke et al. ${ }^{38}$ demonstrated that both the volumes of fat and lean masses in the affected and unaffected limbs of those with lymphedema are associated with whether it is the dominant or non-dominant limb that is affected, as well as the severity of lymphedema. The subgroup with moderate to severe lymphedema had the greatest inter-limb differences in fat and lean tissues ${ }^{38}$. In this study, all degrees of lymphedema were considered.

To date, research has found that in healthy populations, the right arm has slightly less fat and slightly more lean tissues than the left arm ${ }^{39}$. For individuals with severe lymphedema, large increases in the volumes of fat and lean tissues were found in the affected side ${ }^{40}$. In this study, body composition changes in upper limbs and trunk were also observed but it is not possible to infer a mechanism that associates presence of lymphedema with body composition changes.

Researchers have postulated that breast cancer survivors exhibit reduction in muscle strength associated with cancerrelated symptoms ${ }^{19,20}$. Interestingly, handgrip strength in women with presence or absence of lymphedema was similar. The time after surgery may have been decisive for the results of this study. More significant changes in body composition are observed according to the type of surgery and presence of lymphedema six months after surgery. Nevertheless, the handgrip strength was not associated with presence of lymphedema.

Some limitations of the study could have contributed to not be possible to clarify the relationship between body composition and type of surgery, body composition and presence of lymphedema, and lymphedema and handgrip strength, such as: assessments conducted six months after surgery; different stages of lymphedema; no baseline measures prior to surgery, comparisons between groups 
were based on results of other women (CG) since this group showed similar data to cross-sectional studies ${ }^{14,15}$; and limited number of participants in the study.

Body composition change of the trunk was a relevant scientific finding. Investigations have reported body composition changes only in the arm after breast cancer $^{38,40}$. Such alterations could cause onset of the functional disorders like fatigue, pain, and movement limitations. In conclusion, breast cancer survivors have changes in body composition and in handgrip strength six months after surgery; however, the interaction between the type of surgery and its impact is unclear. Furthermore, women who developed lymphedema in this period showed more significant changes in body composition, which were not enough to cause impairment in the handgrip strength.

\section{References}

1. Adriaenssens N, Vinh-Hung V, Miedema G, Versmessen $H$, Lamote J, Vanhoeij $M$, et al. Early contralateral shoulderarm morbidity in breast cancer patients enrolled in a randomized trial of post-surgery radiation therapy. Breast Cancer (Auckl). 2012;6:79-93.

2. Cantarero-Villanueva I, Fernández-Lao C, Díaz-Rodríguez L, Fernándezde-Las-Peñas C, Ruiz JR, Arroyo-Morales M. The handgrip strength test as a measure of function in breast cancer survivors: relationship to cancer-related symptoms and physical and physiologic parameters. Am J Phys Med Rehabil. 2012;91(9):774-82.

3. Nagel PH, Bruggink ED, Wobbes T, Strobbe LJ. Arm morbidity after complete axillary lymph node dissection for breast cancer. Acta Chir Belg. 2003;103(2):212-6.

4. Nesvold IL, Reinertsen KV, Fosså SD, Dahl AA. The relation between arm/shoulder problems and quality of life in breast cancer survivors: a cross-sectional and longitudinal study. J Cancer Surviv. $2011 ; 5(1): 62-72$.

5. Fernández-Lao $C$, Cantarero-Villanueva I, Fernández-de-Las-Peñas $C$, Del-Moral-Ávila R, Arendt-Nielsen L, Arroyo-Morales M. Myofascial trigger points in neck and shoulder muscles and widespread pressure pain hypersensitivtiy in patients with postmastectomy pain: evidence of peripheral and central sensitization. Clin J Pain. 2010;26(9):798-806

6. Cavalli Kluthcovsky AC, Urbanetz AA, de Carvalho DS, Pereira Maluf EM, Schlickmann Sylvestre GC, Bonatto Hatschbach SB. Fatigue after treatment in breast cancer survivors: prevalence, determinants and impact on health-related quality of life. Support Care Cancer. 2012;20(8):1901-9.

7. Gomide LB, Matheus JP, Reis FJ. Morbidity after breast cancer treatment and physiotherapeutic performance. Int J Clin Pract. 2007;61 (6):972-82.

8. Wilmoth MC, Coleman EA, Smith SC, David C. Fatigue, weight gain, and altered sexuality in patients with breast cancer: exploration of a symptom cluster. Oncol Nurs Forum. 2004;31:1069-75.

9. McDonald CK, Baver JD, Capra S. Body composition and breast cancer- the role of lean body mass. Cancer Forum. 2011;35:102-6.

10. McDonald C, Bauer J, Capra S, Waterhouse M. Muscle function and omega-3 fatty acids in the prediction of lean body mass after breast cancer treatment. Springerplus. 2013;2:681. doi:10.1186/2193. 1801-2-681. eCollection 2013.

11. Demark-Wahnefried W, Winer EP, Rimer BK. Why women gain weight with adjuvant chemotherapy for breast cancer. J Clin Oncol. $1993 ; 11(7): 1418-29$
12. Norman K, Stobaus N, Gonzalez MC, Schulzke JD, Pirlich M. Hand grip strength: outcome predictor and marker of nutritional status. Clin Nutr. $2011 ; 30(2): 135-42$.

13. Bar Ad V, Dutta PR, Solin L, Hwang WT, Tan KS, Both S, et al. Time-course of arm lymphedema and potential risk factors for progression of lymphedema after breast conservation treatment for early stage breast cancer. Breast J. 2012;18(3):219-25.

14. Schlüssel MM, dos Anjos LA, de Vasconcellos MT, Kac G. Reference values of handgrip dynamometry of healthy adults: a populationbased study. Clin Nutr. 2008;27(4):601-7.

15. Schutz Y, Kyle UU, Pichard C. Fat-free mass index and fat mass index percentiles in Caucasians aged 18-98 y. Int J Obes Relat Metab Disord. 2002;26(7):953-60.

16. American Cancer Society [Internet]. Cancer facts \& figures 2011 [cited 2012 May 20]. Available from: <http://www.cancer.org/ acs/groups/content/@epidemiologysurveilance/documents/ document/acspc-029771.pdf>

17. National Cancer Institute. Surveillance, Epidemiology, and End Results Program [Internet]. SEER Cancer Statistics Review, 1975-2009 [cited 2011 Sep 10]. Available from: <http://seer. cancer.gov/archive/csr/1975_2009_pops09/>

18. Bosompra K, Ashikaga T, O’Brien PJ, Nelson L, Skelly J. Swelling, numbness, pain, and their relationship to arm function among breast cancer survivors: a disablement process model perspective. Breast J. 2002;8(6):338-48.

19. Winters-Stone KM, Bennett JA, Nail L, Schwartz A. Strength, physical activity, and age predict fatigue in older breast cancer survivors. Oncol Nurs Forum. 2008;35(5):815-21.

20. Cantarero-Villanueva I, Fernández-Lao C, Fernández-de-LasPeñas C, Díaz-Rodrígues L, Sanchez-Cantalejo E, ArroyoMorales M. Associations among musculoskeletal impairments, depression, body image and fatigue in breast cancer survivors within the first year after treatment. Eur J Cancer Care (Engl). $2011 ; 20(5): 632-9$.

21. Laukkanen $P$, Heikkinen $E$, Kauppinen M. Muscle strength and mobility as predictors of survival in 75-84-year-old people. Age Ageing. 1995;24(6):468-73.

22. Gale CR, Martyn CN, Cooper C, Sayer AA. Grip strength, body composition, and mortality. Int J Epidemiol. 2007;36(1):228-35.

23. Sasaki H, Kasagi F, Yamada M, Fujita S. Grip strength predicts cause-specific mortality in middle-aged and elderly persons. Am J Med. 2007;120(4):337-42. 
24. Rantanen T, Volpato S, Ferrucci L, Heikkinen E, Fried LP, Guralnik JM. Handgrip strength and cause-specific and total mortality in older disabled women: exploring the mechanism. J Am Geriatr Soc. 2003;51(5):636-41 .

25. Rooney $M$, Wald $A$. Interventions for the management of weight and body composition changes in women with breast cancer. Clin J Oncol Nurs. 2007;1 1(1):41-52.

26. Harvie M. The importance of controlling body weight after a diagnosis of breast cancer: the role of diet and exercise in breast cancer patient management. In: Saxton J, Daley A, editors. Exercise and cancer survivorship: impact on health outcomes and quality of life. New York: Springer; 2010. p. 73-96.

27. Mourtzakis M, Bedbrook M. Muscle atrophy in cancer: a role for nutrition and exercise. Appl Physiol Nutr Metab. 2009;34(5):950-6.

28. Nichols HB, Trentham-Dietz A, Egan KM, Titus-Ernstoff L, Holmes MD, Bersch $\mathrm{A}$, et al. Body mass index before and after breast cancer diagnosis: associations with all-cause, breast cancer, and cardiovascular disease mortality. Cancer Epidemiol Biomarkers Prev. 2009; 18(5): 1403-9.

29. Healy LA, Ryan AM, Carroll P, Ennis D, Crowley V, Boyle T, et al. Metabolic syndrome, central obesity and insulin resistance are associated with adverse pathological features in postmenopausal breast. Clin Oncol (R Col Radiol). 2010;22(4):281-8.

30. Argilés JM, Busquets S, Felipe A, López-Soriano FJ. Molecular mechanisms involved in muscle wasting in cancer and ageing: cachexia versus sarcopenia. Int J Biochem Cell Biol. 2005;37(5):1084-104.

31. Schaap LA, Pluijm SM, Deeg DJ, Visser M. Inflammatory markers and loss of muscle mass (sarcopenia) and strength. Am J Med 2006; $119(6): 526 . e 9-17$
32. Lexell J. Evidence for nervous system degenration with advancing age. J Nutr. 1997;127(5 Suppl):1011S-1013S.

33. Clarkson PM, Kaufman SA. Should resistance exercise be recommended during breast cancer treatment? Med Hypotheses. 2010;75(2):192-5.

34. Clark BC, Manini TM. Sarcopenia $\neq$ dynapenia. J Gerontol A Biol Sci Med Sci. 2008;63(8):829-34.

35. Armer JM, Stewart BR. A comparison of four diagnostic criteria for lymphedema in a post-breast cancer population. Lymphat Res Biol. 2005;3(4):208-17.

36. Wilke LG, McCall LM, Poshther KE, Whitworth PW, Reintgen DS, Leitch AM, et al. Surgical complications associated with sentinel lymph node biopsy: results from a prospective international cooperative group trial. Ann Surg Oncol. 2006;13(4):491-500.

37. Armer J, Fu MR, Wainstock E, Zagar E, Jacobs LK. Lymphedema following breast cancer treatment, including sentinel lymph node biopsy. Lymphology. 2004;37(2):73-91.

38. Dylke ES, Ward LC, Meerkin JD, Nery L, Kilbreath SL. Tissue composition changes and secondary lymphedema. Lymphat Res Biol. 2013;1 1(4):211-8.

39. Coin A, Giannini S, Minicuci N, Rinaldi G, Pedrazzoni M, Minisola $S$, et al. Limb fat-free mass and fat mass reference values by dualenergy X-ray absorptiometry (DEXA) in a 20-80 year-old italian population. Clin Nutr. 2012;31(4):506-1 1 .

40. Brorson H, Ohlin K, Olsson G, Karlsson MK. Breast cancerrelated chronic arm lymphedema is associated with excess adipose and muscle tissue. Lymphat Res Biol. 2009;7(1):3-10. 